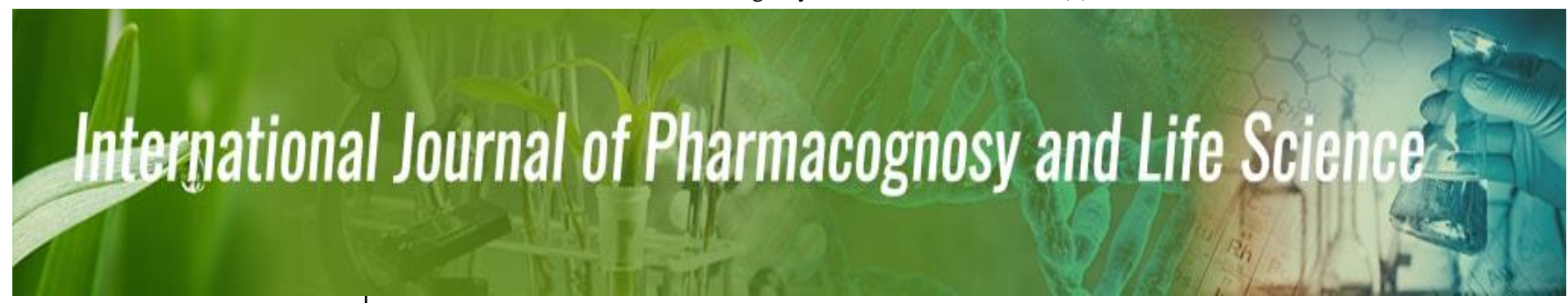

E-ISSN: 2707-2835

P-ISSN: 2707-2827

IJPLS 2020; 1(1): 33-37

Received: 21-11-2019

Accepted: 23-12-2019

Rakesh Kumar Joshi Lecturer Chemistry, Department of Education, Government of Uttarakhand, India

\section{Rachid Soulimani}

Université de Lorraine, LCOMS/ Neurotoxicologie Alimentaire ET Bioactivité Campus Bridoux, Metz, France

Corresponding Author: Rakesh Kumar Joshi Lecturer Chemistry, Department of Education, Government of Uttarakhand, India

\section{Ethno-medicinal and phytochemical potential of Carum carvi Linn. and Cuminum cyminum: A review}

\author{
Rakesh Kumar Joshi, Rachid Soulimani
}

DOI: https://doi.org/10.33545/27072827.2020.v1.i1a.7

\begin{abstract}
Caraway (Carum carvi L.) is a biennial plant in the family Apiaceae. Its seeds (fruits) which are used in food, cosmetics, beverage and pharmaceutical industries. Processed products from caraway whole seed, such as seed powder, essential oil, fatty oil, oleoresins and caraway carvone are widely used in the food and medicinal industries. Caraway is one of the earliest cultivated herbs in Asia, Europe and Africa. The caraway seeds are considered as antispasmodic, carminative, astringent and used in the treatment of stomach stimulant, diarrhea, dyspepsia, hysteria, flatulent indigestion, colic, dyspeptic headache and improve liver function. In ancient Indi an ayurvedic literature use of $C$. carvi seeds is well documented Scientist working in different parts of the world has now experimentally proved the validity of ancient therapeuti c uses of $C$. carvi seeds. This will strengthen our the use of caraway seeds in traditional system of ayurvedic treatments by $C$. carvi seeds.
\end{abstract}

Keywords: Caraway, bioactivity, antioxidant activity, limonene

\section{Introduction}

MPs play a vital role in the development of new drugs and the forests of India have been a source of traditional medicines for millennia. Of the 17,000 species of higher plants described in India, 7500 are known for their medicinal uses ${ }^{[1-3]}$. The Charak Samhita, a document on herbal therapy written about $300 \mathrm{BC}$, reports on the production of 340 herbal drugs and their indigenous uses ${ }^{[4]}$. The Indian Himalayan Region is well known to have a great range of plant diversity. The state of Uttarakhand is a part of north-western Himalaya, and still maintains a dense vegetation cover (65\%). The maximum species of medicinal plants have been reported from Uttarakhand ${ }^{[5-6]}$. This region alone supports about 18,440 plant species (Angiosperm: 8,000 spp., Gymnosperm: 44 spp., Pteridophytes: 600 spp., Bryophytes: 1,736. Lichens: 1,159 spp. and fungi: 6,900 spp ${ }^{[7]}$. According to Samant et al. out of the total vascular plant species, 1,748 species are of medicinal uses ${ }^{[8]}$. Cumin (Cuminum cyminum) and Caraway (Carum carvi L.), from the; Umbelliferae; Apiaceae family, is one of the common well-known herbs, naturally found in Europe, West Asia, Siberia, Turkey, Iran, India and North Africa. In India, now cultivated in Bihar, Orrisa, Punjab, Bengal, Andhra Pradesh and hills of Kumaon and Garhwal, Chamba and Kashmir. Also found in the North Himalayan regions.It is known as Caraway in English, Krishna jiraka in Ayurved. It used as Carminatives, antispasmodic, antimicrobial etc. Its seed oil is used in dyspeptic problems, such as mild, spatic conditions of gastrointestinal tract. The seed oil contains a volatile oil consisting of carvone and limonene with other constituents; flavonids mainly quercetin derivatives as a fixed oil ${ }^{[9]}$. In our previously published research and review articles we have published about essential oil, biological and medicinal values of some Himalayan medicinal plants ${ }^{[10-22]}$. The search for the chemical compositions and pharmacological activities exhibited by the isolated bioactive constituents and/or by the crude extracts was carried out using various searches.

\section{Ethno-medicinal uses}

In Indian therapeutic system a large number of medicinal herbs of various taxonomic genera are included in many forms in this traditional therapy. Literature survey revealed that cumin as well as caraway seeds are prominently considered carminative, eupeptic, antispasmodic, astringent and used in the treatment of mild digestive disorders, diarrhea, dyspepsia, 
Flatulence, morning sickness, colic, dyspeptic headache and bloating, and are said to promote the assimilation of other herbs and to improve liver function ${ }^{[23-24]}$. Essential oils from caraway seeds are reported to give relief in patients suffering from lumbago and rheumatism ${ }^{[25]}$. Caraway water finds use as a vehicle for pediatric medicines. As a mixture with alcohol and castor oil, it has been used for the treatment of scabies ${ }^{[26]}$. In fact, medicinal usage of cumin and caraway seeds has also been immensely widespread in diverse ethno-medicinal systems from Northern Europe to the Mediterranean regions, Russia, Iran, Indonesia and North America, where these have remained as an integral part of their folk medicines. In Iranian traditional medicine, cumin is considered stimulant, carminative and astringent and its therapeutic effects have been described on gastrointestinal, gynecological and respiratory disorders, and also for the treatment of toothache, diarrhea and epilepsy ${ }^{[27]}$. In the Moroccan traditional medicine, caraway seeds are used as diuretics ${ }^{[28]}$ and given to treat diabetes and hypertension ${ }^{[29]}$.

In traditional medicine of Tunisia, cumin is considered abortive, galactagogue, antiseptic, antihypertensive herb, while in Italy, it is used as bitter tonic, carminative, and purgative ${ }^{[30]}$. In indigenous Arabic medicines, the seeds are documented as stimulant, carminative, and attributed with cooling affect and therefore form an ingredient of most prescriptions for gonorrhea, chronic diarrhea and dyspepsia; externally, they are applied in the form of poultice to allay pain and irritation of worms in the abdomen. Seeds reduced to powder, mixed with honey, salt and butter are applied to scorpion bites ${ }^{[31]}$. In Poland, caraway is recommended as a remedy to cure indigestion, flatulence, lack of appetite, and as a galactagogue. In Russia, it is also used to treat pneumonia. In Great Britain and USA, it is regarded a stomachic and carminative. In Malay Peninsula, caraway is one important medicinal herb, and in Indonesia, it is used in the treatment of inflamed eczema ${ }^{[32]}$.

\section{Biological activities}

Literature survey revealed that Cumin (Cuminum cyminum) and Caraway (Carum carvi L.) products (oils as well as their aqueous and solvent derived extracts) have shown significant number of biological activities in many ways. A summary of all those given in table.

Table 1: Biological activities

\begin{tabular}{|c|c|c|}
\hline $\begin{array}{c}\text { Type of } \\
\text { Bioactivity }\end{array}$ & Descriptions about activity & References \\
\hline $\begin{array}{c}\text { Antioxidant } \\
\text { activity }\end{array}$ & $\begin{array}{c}\text { Essential oils and extract of different parts of cumin (Cuminum cyminum) have shown significant antioxidant } \\
\text { activity in several test methods, as quench hydroxyl radicals, 1, 1-diphenyl-2-picrylhydrazyl (DPPH) radicals } \\
\text { and lipid peroxides. The other assays employed were ferric thiocyanate method in linoleic acid system, } \\
\mathrm{Fe}^{2+} \text { ascorbate-induced rat liver microsomal lipid peroxidation (LPO), soybean lipoxygenase dependent lipid } \\
\text { peroxidation and ferric reducing ability. Caraway (Carum carvi L.) root extract has also shown significant anti- } \\
\text { DPPH radical activity. }\end{array}$ & [33-37] \\
\hline $\begin{array}{l}\text { Antimicrobial } \\
\text { activity }\end{array}$ & $\begin{array}{c}\text { Investigations revealed that antimicrobial activity of cumin (Cuminum cyminum) and caraway } \\
\text { (Carum carvi L.) products (essential oils as well as their aqueous and solvent derived extracts). This } \\
\text { antibacterial action was assessed against a range of useful and pathogenic gram-positive and gram-negative } \\
\text { bacterial strains. Cumin seed oil and alcoholic extract inhibited the growth of Klebsiella pneumoniae and its } \\
\text { clinical isolates and caused improvement in cell morphology, capsule expression and decreased urease activity. } \\
\text { This property was attributed to cuminaldehyde biofilm-formation preventive properties were found } \\
\text { against Streptococcus mutans and Streptococcus pyogenes. }\end{array}$ & [38-48] \\
\hline $\begin{array}{l}\text { Antidiabetic } \\
\text { activity }\end{array}$ & 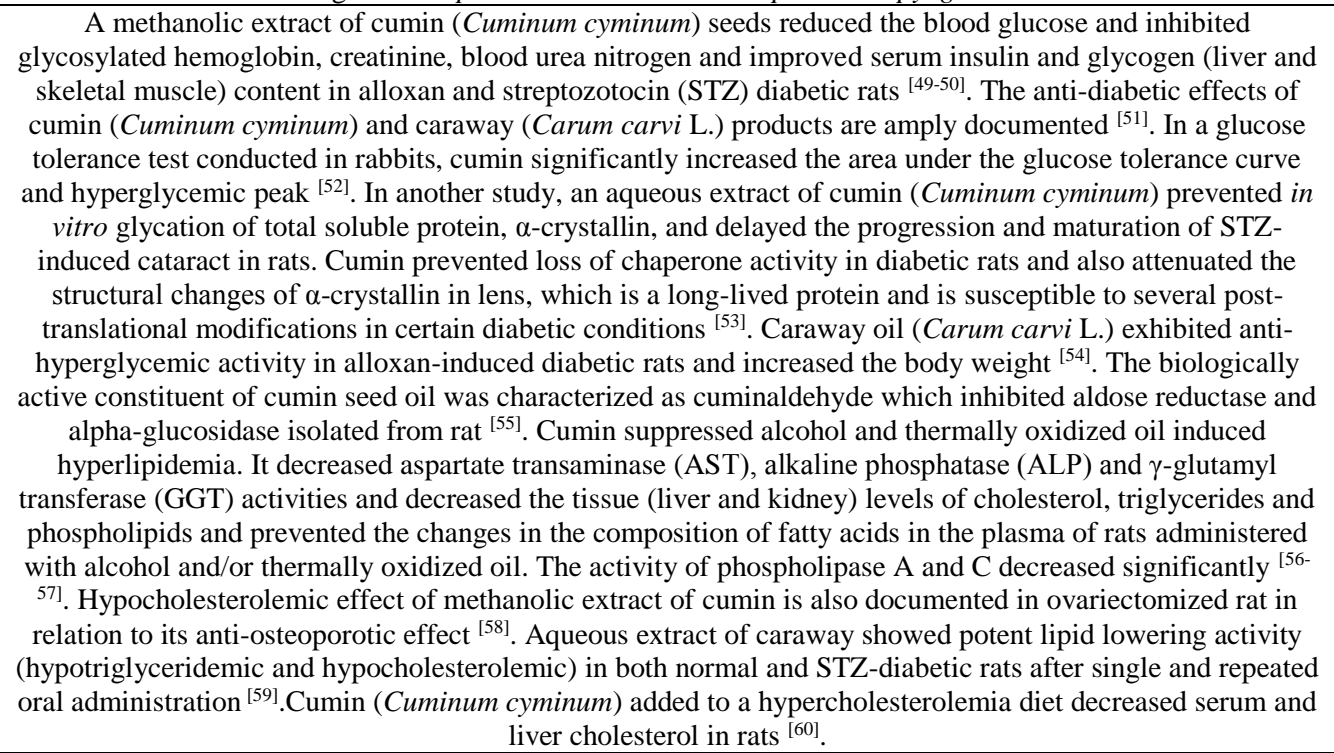 & [49-60] \\
\hline Diuretic activity & $\begin{array}{l}\text { The traditional use of caraway as a diuretic was confirmed in an experimental study in which peroral treatment } \\
\text { of an aqueous extract of caraway (in acute and sub-chronic mode) was shown to increase the urine output } \\
\text { during and after } 24 \text { hours in rat. The urinary levels of sodium and potassium were found to be increased, while } \\
\text { in plasma these were not affected. Carum (Carum carvi L.) extract did not produce any renal toxicity or any } \\
\text { other adverse effects during the study period }{ }^{[61]} \text {. }\end{array}$ & [61] \\
\hline $\begin{array}{c}\text { Gastrointestinal } \\
\text { activity }\end{array}$ & $\begin{array}{l}\text { In human trial studies, some herbal preparations consisting predominantly caraway (Carum carvi L.) have } \\
\text { shown efficacy in relieving dyspeptic symptoms }{ }^{[62]} \text {. The antispasmodic effect of an alcoholic extract of } \\
\text { caraway has shown inhibitory effects on smooth muscle contractions induced by the spasmogens, acetylcholine }\end{array}$ & [62-66] \\
\hline
\end{tabular}




\begin{tabular}{|c|c|c|}
\hline & $\begin{array}{l}\text { and histamine }{ }^{[63-64]} \text {. Extracts from caraway produced dose-dependent antiulcerogenic effect against } \\
\text { indomethacin-induced gastric ulcers, accompanied by reduction in acid and leukotrienes' output, and increased } \\
\text { mucin secretion and prostaglandin E2 release. The antiulcerogenic activity was also confirmed histologically } \\
\text { and was attributed to its flavonoid content and free radical scavenging properties }{ }^{[65]} \text {. Aqueous and solvent } \\
\text { derived extracts of cumin (Cuminum cyminum) increased amylase, protease, lipase and phytase activities }{ }^{[66]} \text {. }\end{array}$ & \\
\hline CNS activity & $\begin{array}{l}\text { Anti-epileptic activity of fruit essential oil of (Cuminum cyminum) is documented. It decreased the frequency } \\
\text { of spontaneous activity induced by pentylenetetrazol (PTZ). This protection was measured in a time- and } \\
\text { concentration-dependent manner as increased duration, decreased amplitude of hyperpolarization potential, the } \\
\text { peak and firing rate of action potential and excitability of nerve cells }{ }^{[67]} \text {. Cumin oil was found to attenuate } \\
\text { seizures induced by maximal electroshock and PTZ in mice }{ }^{[68]} \text {. Cumin oil has also been found to possess } \\
\text { significant analgesic action in a chemical model (formalin test) of nociception in rat }{ }^{[69]} \text {. }\end{array}$ & [67-69] \\
\hline $\begin{array}{l}\text { Immunomodulatory } \\
\text { activity }\end{array}$ & $\begin{array}{l}\text { In a recent study, oral treatment with cumin showed immunomodulatory properties in normal and immune- } \\
\text { suppressed animals via modulation of T lymphocytes' expression in a dose-dependent manner. It stimulated the } \\
\mathrm{T} \text { cells' (CD4 and CD8) and Th1 cytokines' expression in normal and cyclosporine-A induced immune- } \\
\text { suppressed mice. In restraint stress-induced immune-suppressed animals, the active compound of cumin } \\
\text { countered the depleted T Tymphocytes, decreased the elevated corticosterone levels and size of adrenal glands } \\
\text { and increased the weight of thymus and spleen }{ }^{[70]} \text {. }\end{array}$ & {$[70]$} \\
\hline
\end{tabular}

\section{Chemical composition:}

Caraway (Carum carvi L.) seeds contain several components; major phytochemicals of $C$. carvi essential oil were $37.98 \%$ (R)-carvone, $26.55 \%$ D-limonene, $5.21 \%$ apinene, $5.01 \%$ cis-carveol and $4.67 \%$ B-myrcene ${ }^{[71]}$. The essential oil of $C$. carvi was also characterized by high contents of oxygenated monoterpenes (62. 17\%), monoterpenes $(36.08 \%)$ and sesqui terpenes $(0.41 \%)$, saturated and unsaturated fatty acids, ketones, aldehydes and esters ${ }^{[72-73]}$. Earlier reports showed that this plant contain a variety of secondary metabolites such as mono and sesquiterpenoids ${ }^{[74]}$, steroids and coumarins ${ }^{[75]}$, flavonoids [76], aromatics and their glucosides, alkaloids and aliphatic compounds [75]. High proportion of sesquiterepene hydrocarbons, limonene, g-cadinene, b-selinene and belemene were observed in GC/MS analyzed flower volatiles of $C$. carvi seeds ${ }^{[74]}$. Kunzemann et al. ${ }^{[77]}$.

\section{Conclusions}

Carum carvi L. seeds are rich sources of essential oils containing diverse group of phytochemicals. It has abroad spectrum pharmacological effect in treatment of traditional healing systems in different parts of the world. In last two decades extensive studies has been carried on Carum carvi L. seeds to explore its full potential of pharmacological action. A natural product used in conventional treatment provides a clue for the existence of phytochemicals. New researches on caraway proved it as a source of new entities to perform different pharmacodynamic properties, responsible for their pharmacological effects. The present review is a step to promote it for cultivation in large scale in Uttrakhand for improvement of economy of peoples living in hill areas.

\section{Transparency Declaration}

The authors declare no conflicts of interest.

\section{Author's Contributions}

All authors are involved in drafting the manuscript, read and approved the final version of the manuscript.

\section{References}

1. Stainton JDA. Forests of Nepal. John Murray Ltd, London U.K, 1972.

2. Alves R, Rosa I. Biodiversity traditional medicine and public health: where do they meet? J Ethnobiol Ethnomed. 2007; 3:1-9.
3. Shiva MP. Inventory of forestry resources for sustainable management and biodiversity conservation. New Delhi, Indus Publishing Company, 1996.

4. Prajapati ND, Purohit SS, Sharma AK, Kumar T. A handbook of medicinal plants, Jodhpur, Agro bios; 2003.

5. Singh D, Srivastava RK, Khanduri VP. Marketing strategies and trade of medicinal plants in Uttaranchal: Present and future prospects. Indian Forester. 2005; 131(3):330-340.

6. Kala CP. Assessment of species rarity. Current Sci. 2004; 86(8):1058-1059.

7. Singh DK, Hajra PK. Floristic Diversity. In: Biodiversity Status in the Himalaya. Edited by Gujral. British Council, New Delhi, India, 1997, 23-38.

8. Samant SS, Dhar U, Palni LMS. Medicinal Plants of Indian Himalaya: Diversity Distribution Potential Values. Almora: G.B. Pant Institute of Himalayan Environment and Development, 1988.

9. Khare CP. Indian medicinal plants-An illustrated dictionary. Springer Science and Business Media, LLC, 2007, 124-125.

10. Joshi RK. Genus Morina: valuable aromatic plant for herbal drug. VRI Phytomedicine (USA), 2013; 1(2):8184.

11. Joshi RK. Artemisia capillaris: Medicinal uses and future source for commercial uses from Western Himalaya of Uttrakhand. Asian J. Res. Pharm. Sci. 2013; 3(3):137-140.

12. Joshi RK. Chemical composition of Filipenduala vestita from India. Chemistry of Natural Compounds 2015; 1:169-170.

13. Joshi RK. Volatile oils composition of Artemisia japonica Thunb. from Western Himalaya of Uttarakhand. Journal of Pharmacognosy and Phytochemistry. 2015; 3(5):96-97.

14. Joshi RK, Setzer WN, Junior Valdir F. da Veiga. Aromatic and medicinal plants with anti-diabetic potential from India: A review. American Journal of Essential Oils and Natural Products. 2015; 2(4):22-28.

15. Joshi RK, Satyal P, Setzer WN. Himalayan Aromatic Medicinal Plants: A Review of their Ethno pharmacology, Volatile Phytochemistry, and Biological Activities: Medicines 2016; 3:6 doi:10.3390.

16. Joshi RK. Phytochemical and medicinal aspect of Cordyceps sinensis (Berk.): A review. Journal of Medicinal Plants Studies. 2016; 4(1):65-67. 
17. Joshi RK. Asparagus racemosus (Shatawari), phytoconstituents and medicinal importance, future source of economy by cultivation in Uttrakhand: A review. International Journal of Herbal Medicine. 2016; 4(4):18-21.

18. Joshi RK. Volatile oil composition of aerial parts of Selinum tenuifolium Wall. Ex. C.B. Clarke form western Himalaya of Uttrakhand, India. Journal of Medicinal Plants Studies 2016; 4(5):08-10.

19. Joshi RK. Chemical constituents of leaf essential oils of Heracleum candicans Wall. ex DC from Western Himalaya of Uttrakhand, India. American Journal of Essential Oils and Natural Products. 2016; 4(2):01-04.

20. Joshi RK. Essential oil composition of Thymus linearis (Benth) from western Himalaya of Uttrakhand, India. Asian J. Pharm. Tech. 2016; 6(4):199-201. DOI: 10.5958/2231-5713.2016.00029.5

21. Joshi RK, Setzer WN, da Silva JK. Phytoconstituents, traditional medicinal uses and bioactivities of Tulsi (Ocimum sanctum Linn.): A review. American Journal of Essential Oils and Natural Products, 2016.

22. Joshi RK. Salicylaldihyde rich leaf essential oil composition of Filpendula vestita from Western Himalaya of Uttakhand, India. Vietnam Journal of Science and Technology 2018; 56(4):441-445 DOI: $10.15625 / 2525-2518 / 56 / 4 / 12487$

23. Joshi SG. 1st ed. Delhi: Oxford and IBH Publishing Co. Pvt. Ltd 2000. Medicinal plants: Family Apiaceae.

24. Mhaskar KS, Blatter E, Caius JF, Editors. Vol. 5. New Delhi: Satguru Publications In Kiritikar and Basu's Illustrated Indian Medicinal Plants, 2000.

25. Perry LM. Massachusetts and London: The MIT Press Medicinal Plants of East and Southeast Asia, 1980.

26. Sivarajan VV, Balachandran I. New Delhi: Oxford and IBH Publication. Ayurvedic Drugs and their Plant Sources, 1994

27. Zargary A. 5th ed. Tehran: Tehran University Publications Medicinal Plants, 2001.

28. Lahlou S, Tahraoui A, Israili Z, Lyoussi B. Diuretic activity of the aqueous extracts of Carum carvi L. and Tanacetum vulgare in normal rats. J Ethnopharmacol. 2007; 110:458-63.

29. Tahraoui A, El-Hilay J, Israili ZH, Lyoussi B. Ethnopharmacological survey of plants used in the traditional treatment of hypertension and diabetes in south-eastern Morocco (Errachidia province) J Ethnopharmacol. 2007; 110:105-17.

30. Leporatti ML, Ghedira K. Comparative analysis of medicinal plants used in traditional medicine in Italy and Tunisia. J Ethnobiol Ethnomed. 2009; 5:31-9.

31. Al-Yahya M, Collpharm A. Phytochemical studies of plant used in traditional medicine in Saudi Arabia. Fitoterapia. 1986; 57:179-82.

32. Sadowska A, Obidoska G. Caraway. In: Nemeth E, Editor. The Genus Carum. USA: CRC Press, 2004.

33. Bettaieb I, Bourgou S, Wannes WA, Hamrouni I, Limam F, Marzouk B. Essential oils, phenolics and antioxidant activities of different parts of cumin (Cuminum cyminum L.) J Agric Food Chem. 2010; 58:10410-8.

34. De Martino L, De Feo V, Fratianni F, Nazzaro F. Chemistry, antioxidant, antibacterial and antifungal activities of volatile oils and their components. Nat Prod Commu. 2009; 4:1741-50.
35. Gachkar L, Yadegari D, Rezaei MB, Taghizadeh M, Astaneh SA, Rasooli I. Chemical and biological characteristics of Cuminum cyminum and Rosemarinus officinalis essential oils. Food Chem. 2007; 102:898904

36. Topal U, Sasaki M, Goto M, Otles S. Chemical compositions and antioxidant properties of essential oils from nine species of Turkish plants obtained by supercritical carbon dioxide extraction and steam distillation. Int. J Food Sci Nutr. 2008; 59:619-34.

37. Najda A, Dyduch J, Brzozowski N. Flavonoid content and antioxidant activity of caraway roots (Carum carvi L.) Veg Crops Res Bull. 2008; 68:127-33.

38. De Martino L, De Feo V, Fratianni F, Nazzaro F. Chemistry, antioxidant, antibacterial and antifungal activities of volatile oils and their components. Nat Prod Commu. 2009; 4:1741-50.

39. Hajlaoui H, Mighri H, Noumi E, Snoussi M, Trabelsi $\mathrm{N}$, Ksouri R et al. Chemical composition and biological activities of Tunisian Cuminum cyminum L.essential oil: A high effectiveness against Vibrio spp. strains. Food Chem Toxicol. 2010; 48:2186-92.

40. Iacobellis NS, Lo Cantore P, Capasso F, Senatore F. Antibacterial activity of Cuminum cyminum L. and Carum carvi L. essential oils. J Agric Food Chem. 2005; 53:57-61.

41. Jirovetz L, Buchbauer G, Stoyanova AS, Georgiev EV, Damianova ST. Composition, quality control and antimicrobial activity of the essential oil of cumin (Cuminum cyminum L.) seeds from Bulgaria that had been stored upto 36 years. Int J Food Sci Technol. 2005; 40:305-10.

42. Singh G, Marimuthu P, Murali HS, Bawa AS. Antiooxidative and antibacterial potentials of essential oils and extracts isolated from various spice materials. $\mathrm{J}$ Food Saf. 2005; 25:130-45.

43. Agnihotri S, Vaidya AD. A novel approach to study antibacterial properties of volatile components of selected Indian medicinal herbs. Indian $\mathbf{J}$ Exp Biol. 1996; 34:712-5.

44. Irkin R, Korukluoglu M. Growth inhibition of pathogenic bacteria and some yeasts by selected essential oils and survival of $L$. monocytogenes and $C$. albicans in apple-carrot juice. 2009; 6:387-94

45. Dorman HJD, Deans SG. Antimicrobial agents from plants: Antibacterial activity of plant volatile oils. J Appl Microbiol. 2000; 88:308-16.

46. Farag RS, Daw ZY, Hewedi FM, El Baroty GSA. Antimicrobial activity of some Egyptian spice essential oils. J Food Prot. 1989; 52:665-7.

47. Derakhshan S, Sattari M, Bigdeli M. Effect of subinhibitory concentrations of cumin (Cuminum cyminum L.) seed essential oil and alcoholic extract on the morphology, capsule expression and urease activity of Klebsiella pneumoniae. Int J Antimicrob Agents. 2008; 32:432-6.

48. Derakhshan S, Sattari M, Bigdeli M. Effect of cumin (Cuminum cyminum L.) seed essential oil on biofilm formation and plasmid integrity by Klebsiella pneumoniae. Pharmacog Mag. 2010; 6:57-61.

49. Dhandapani S, Subramanian VR, Rajagopal S, Namasivayam N. Hypolipidemic effect of Cuminum cyminum L.on alloxan-induced diabetic rats. Pharmacol Res. 2002; 46:251-5. 
50. Jagtap AG, Patil PB. Antihyperglycemic activity and inhibition of advanced glycation end product formation by Cuminum cyminum in streptozotocin induced diabetic rats. Food Chem Toxicol. 2010; 48:2030-6.

51. Srinivasan K. Plant foods in the management of diabetes mellitus: Spices as beneficial antidiabetic food adjuncts. Int J Food Sci Nutr. 2005; 56:399-414.

52. Roman-Ramos R, Flores-Saenz JL, Alarcon-Aguilar FJ. Anti-hyperglycemic effect of some edible plants. J Ethnopharmacol. 1995; 48:25-32.

53. Kumar PA, Reddy PY, Srinivas PN, Reddy GB. Delay of diabetic cataract in rats by the antiglycating potential of cumin through modulation of $\alpha$-crystallin chaperone activity. J Nutr Biochem. 2009; 20:553-62.

54. Ene AC, Nwankwo EA, Samdi LM. Alloxan-induced diabetes in rats and the effects of black caraway (Carum carvi L.) oil on their body weight. Res J Med Med Sci. 2007; 2:48-52.

55. Lee HS. Cuminaldehyde: Aldose Reductase and alphaglucosidase inhibitor derived from Cuminum cyminum L. seeds. J Agric Food Chem. 2005; 53:244653.

56. Aruna K, Rukkumani R, Varma PS, Menon VP. Therapeutic role of Cuminum cyminum on ethanol and thermally oxidized sunflower oil induced toxicity. Phytother Res. 2005; 19:416-21.

57. Kode A, Rajagopalan R, Penumathsa SV, Menon VP. Effect of ethanol and thermally oxidized sunflower oil ingestion on phospholipid fatty acid composition of rat liver: Protective role of Cuminum cyminum L. Ann Nutr Metab. 2005; 49:300-3.

58. Shirke SS, Jagtap AG. Effects of methanolic extract of Cuminum cyminum on total serum cholesterol in ovariectomized rats. Indian J Pharmacol. 2009; 41:923.

59. Lemhadri A, Hajji L, Michel JB, Eddouks M. Cholesterol and triglycerides lowering activities of caraway fruits in normal and streptozotocin diabetic rats. J Ethnopharmacol. 2006; 106:321-6.

60. Sambaiah K, Srinivasan K. Effect of cumin, cinnamon, ginger, mustard and tamarind in induced hypercholesterolemic rats. Nahrung. 1991; 35:47-51.

61. Lahlou S, Tahraoui A, Israili Z, Lyoussi B. Diuretic activity of the aqueous extracts of Carum carvi and Tanacetum vulgare in normal rats. J Ethnopharmacol. 2007; 110:458-63.]

62. Thomson Coon J, Ernst E. Systematic review: Herbal medicinal products for non-ulcer dyspepsia. Aliment Pharmacol Ther. 2002; 16:1689-99.

63. Forster HB, Niklas H, Lutz S. Antispasmodic effects of some medicinal plants. Planta Med. 1980; 40:309-19.

64. Al-Essa MK, Shafagoj YA, Mohammed Fi, Afifi FU. Relaxant effect of ethanol extract of Carum carvion dispersed intestinal smooth muscle cells of the guinea pig. Pharm Biol. 2010; 48:76-80.

65. Khayyal MT, el-Ghazaly MA, Kenawy SA, Seif-elNasr M, Mahran LG, Kafafi YA et al. Antiulcerogenic effect of some gastrointestinally acting plant extracts and their combination. Arzneimittelforschung. 2001; 51:545-53.

66. Milan KSM, Dholakia H, Tiku PK, Vishveshwaraiah P. Enhancement of digestive enzymatic activity by cumin (Cuminum cymonum L.) and role of spent cumin as a bionutrient. Food Chem. 2008; 110:678-83.
67. Janahmadi M, Niazi F, Danyali S, Kamalinejad M. Effects of the fruit essential oil of Cuminum cyminum Linn. (Apiaceae) on pentylenetetrazolinduced epileptiform activity in F1 neurones of Helix aspersa. J Ethnopharmacol. 2006; 104:278-82.

68. Sayyah M, Mahboubi A, Kamalinejad M. Anticonvulsant effect of the fruit essential oil of Cuminum cyminum in mice. Pharmaceut Biol. 2002a; 40:478-80.

69. Sayyah M, Peirovi A, Kamalinejad M. Antinociceptive effect of fruit essential oil of Cuminum cyminum L. in rat. Iran Biomed J. 2002b; 6:141-5.

70. Chauhan PS, Satti NK, Suri KA, Amina M, Bani S. Stimulatory effects of Cuminum cyminum and flavonoid glycoside on cyclosporine-A and restraint stress induced immune-suppression in swiss albino mice.Chem Biol Interac. 2010; 185:66-72.

71. Fang R, Ji ang $\mathrm{CH}$, Wang $\mathrm{XY}$ et al. Insecticidal activity of essential oil of Carum carvi fruits from China and its main components against two grain storage insects. Molecules 2010; 15(1, 2):9391-9402. doi: 10. 3390/molecules15129391

72. Simic A, Rancic A, Sokovic MD et al. Essential oil composition of Cymbopogon winterianus and Carum carvi and their antimicrobial activities. Pharm Biol. 2008; 46:437-441. doi: 10. 1080/1388020080205591 7

73. Meshkatal SMH, Salahvarzi BS. Identification of essential oil constituents of caraway (Carum carvi) using ultrasonic assist with headspace solid phase micro extraction (UA-HS-SPME). Di g J Nanomater Bios. 2012; 7(2):637-640

74. Khaleel AES. Volatiles from flowers of selected apiaceous species. Egy J Biomed Sci. 2004; 15:102113.

75. Kartinig T, Scholz G, Fette S. Component lipids of the fruits of Pimpinella anisum and Carum carvi. Fette Seifen Anstri chm. 1969; 71(4):276-280. doi: 1 0. 1 002/ 1 i pi. 19690710406

76. Kunzemann J, Herrmann K, Zei tschriff F. Isolation and identification of flavon-O-gl ycosi des i n Caraway (Carum carvi L.) fennel (Foeniculum vulgare Mill), anise (Pimpinella anisum L.) and Coriander (Coriandrum sativum L.) and of flavone-C-glycosi desinanise. Zeitschr Lebensm Undersuch Forchung. 1977; 164(3):194-200. doi: 10. 1 007/BF01 263030

77. Ngo-Duy C, Destaillats F, Keskitalo M, Arul J, Angers P. Triacylglerols of Apiaceae seed oils: composition and region distribution of fatty acids. Eur J Lipid Sci Technol. 2009; 111(2):164-169. doi: 10. 1002/ej lt. 200800178 